\title{
Detection of seven species of pathogenic leptospires by PCR using two sets of primers
}

\author{
C. Gravekamp, ${ }^{1 *}$ H. Van de Kemp, ${ }^{1}$ M. Franzen, ${ }^{1}$ D. Carrington, ${ }^{2}$ G. J. Schoone, ${ }^{1}$ \\ G. J. J. M. VAN Eys, ${ }^{3}$ C. O. R. Everard, ${ }^{2}$ R. A. Hartskeerl ${ }^{1}$ and W. J. Terpstra ${ }^{1}$ \\ ${ }^{1}$ NH Swellengrebel Laboratory for Tropical Hygiene, Royal Tropical Institute, WHO/FAO Collaborating Centre for \\ Reference and Research on Leptospirosis, Meibergdreef 39, 1105 AZ Amsterdam, The Netherlands \\ ${ }^{2}$ Medical Research Council/Government of Barbados Leptospirosis Laboratory, Lower Collymore Rock, Enmore 2, \\ St Michael, Barbados \\ ${ }^{3}$ University of Limburg, Department of Molecular Cell Biology, Postbus 616, 6200 MO Maastricht, The Netherlands
}

(Received 9 October 1992; revised 4 March 1993; accepted 9 March 1993)

\begin{abstract}
Two sets of primers derived from genomic DNA libraries of Leptospira serovars icterohaemorrhagiae (strain RGA) and bim (strain 1051) enabled the amplification by PCR of target DNA fragments from leptospiral reference strains belonging to all presently described pathogenic Leptospira species. The icterohaemorrhagiae-derived primers (G1/G2) enabled amplification of DNA from $L$. interrogans, L. borgpetersenii, L. weilii, L. noguchii, $L$. santarosai and $L$. meyeri, whereas the bim-derived primers (B64-I/B64-II) enabled the amplification of L. kirschneri. Southern blot and DNA sequence analysis revealed inter-species DNA polymorphism within the region spanned by primers G1 and G2 between $L$. interrogans and various other Leptospira species. Using a mixture of primer sets G1/G2 and B64-I/B64-II, leptospires of serovars icterohaemorrhagiae, copenhageni, hardjo, pomona, grippotyphosa and bim were detected in serum samples collected from patients during the first 10 days after the onset of illness.
\end{abstract}

\section{Introduction}

Leptospirosis is probably the world's most widespread zoonosis (Turner, 1970). Early treatment with antibiotics and haemodialysis have contributed to the decrease of mortality (Centers for Disease Control, 1981; Sanford, 1984). Rapid diagnosis of leptospirosis is important in view of an adequate early treatment. Clinically, it is of sufficient importance to be able to state if a patient is infected with pathogenic leptospires or not. Epidemiologically, it is of added value if one can state the nature of the causative leptospiral strain. Conventional classification at the subspecies level of leptospires is based on antigenic similarities with the serovar as a basic taxon. Thus far, more than 200 serovars have been identified divided over 23 serogroups of antigenically similar serovars (Kmety \& Dikken, 1988).

In 1987, Yasuda et al. proposed a new classification of the genus Leptospira in which the old pathogenic species

*Author for correspondence. Tel. 20 5665431; fax 206971841.

Abbreviations: GuSCN, guanidinium thiocyanate; MAT, microscopic agglutination test.
$L$. interrogans and the saprophytic $L$. biflexa each were subdivided into a number of new species. This genetic classification, which is based on DNA homology and does not follow distinctions or clustering based on antigenic similarities, divides leptospiral strains into four non-pathogenic species, L. biflexa, L. meyeri, L. parva, and $L$. wolbachii, and seven pathogenic species, $L$. interrogans, L. borgpetersenii, L. weilii, L. noguchii, $L$. santarosai, $L$. inadai, and $L$. kirschneri (Ramadass et al., 1992). L. kirschneri corresponds largely to an unofficially named species $L$. alstoni (A. F. Kaufmann, personal communication).

Clearly, serology does not contribute to early diagnosis of leptospirosis as antibodies become detectable on approximately the seventh day of disease. Leptospires circulate through the blood of a patient until approximately the 10th day after the onset of symptoms. Conventional methods to detect leptospires in blood such as dark field microscopy or culturing are either unreliable or too slow to contribute to an early diagnosis (Turner, 1970; Faine, 1982). Immunofluorescence staining (Sheldon, 1953; White \& Ristic, 1959), immunoperoxidase staining (Terpstra et al., 1983) and DNA hybridization (Terpstra et al., 1986) are useful methods 
Table 1. Leptospiral strains tested by PCR

All strains were tested two or more times and gave reproducible results.

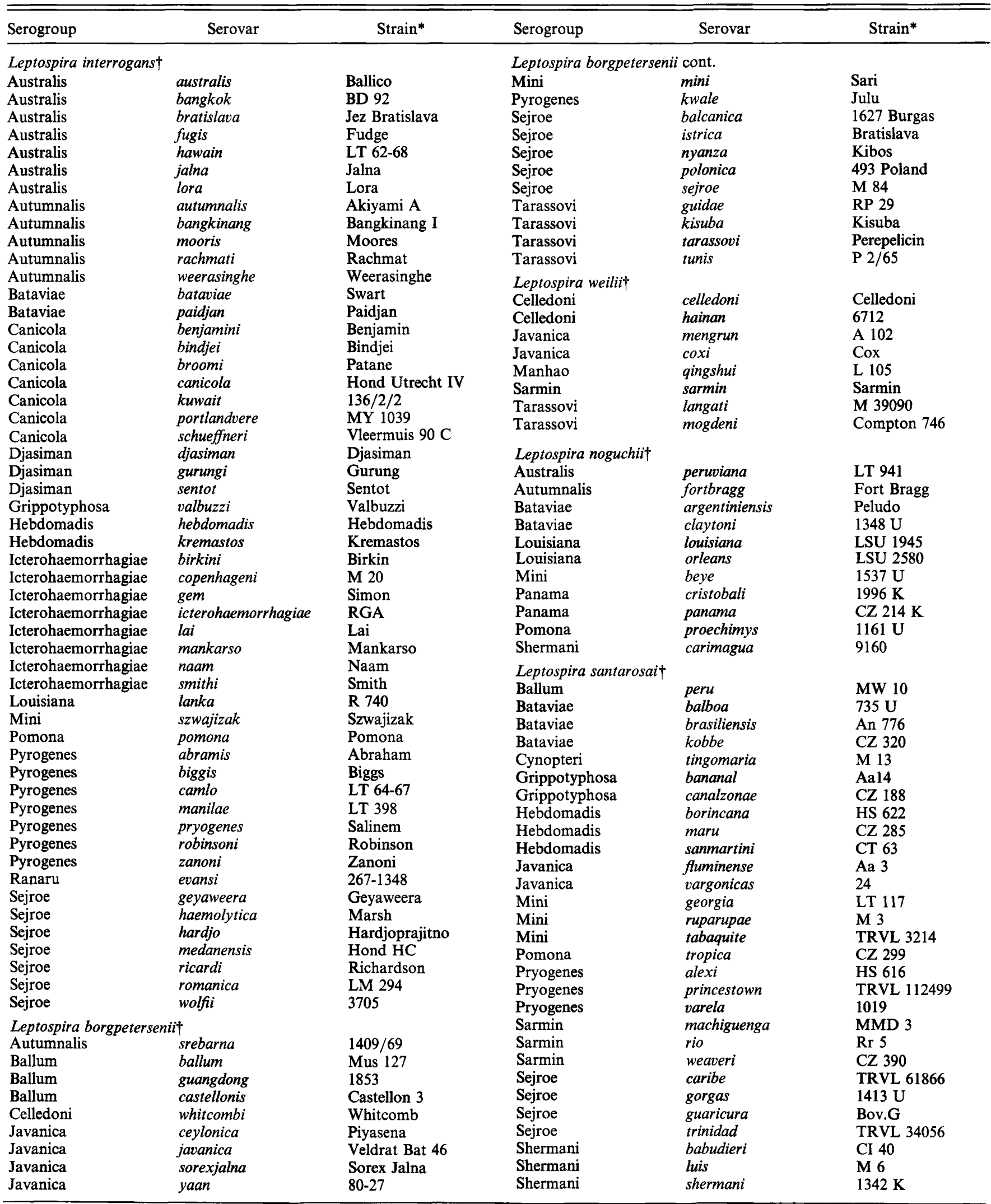


Table 1. (cont.)

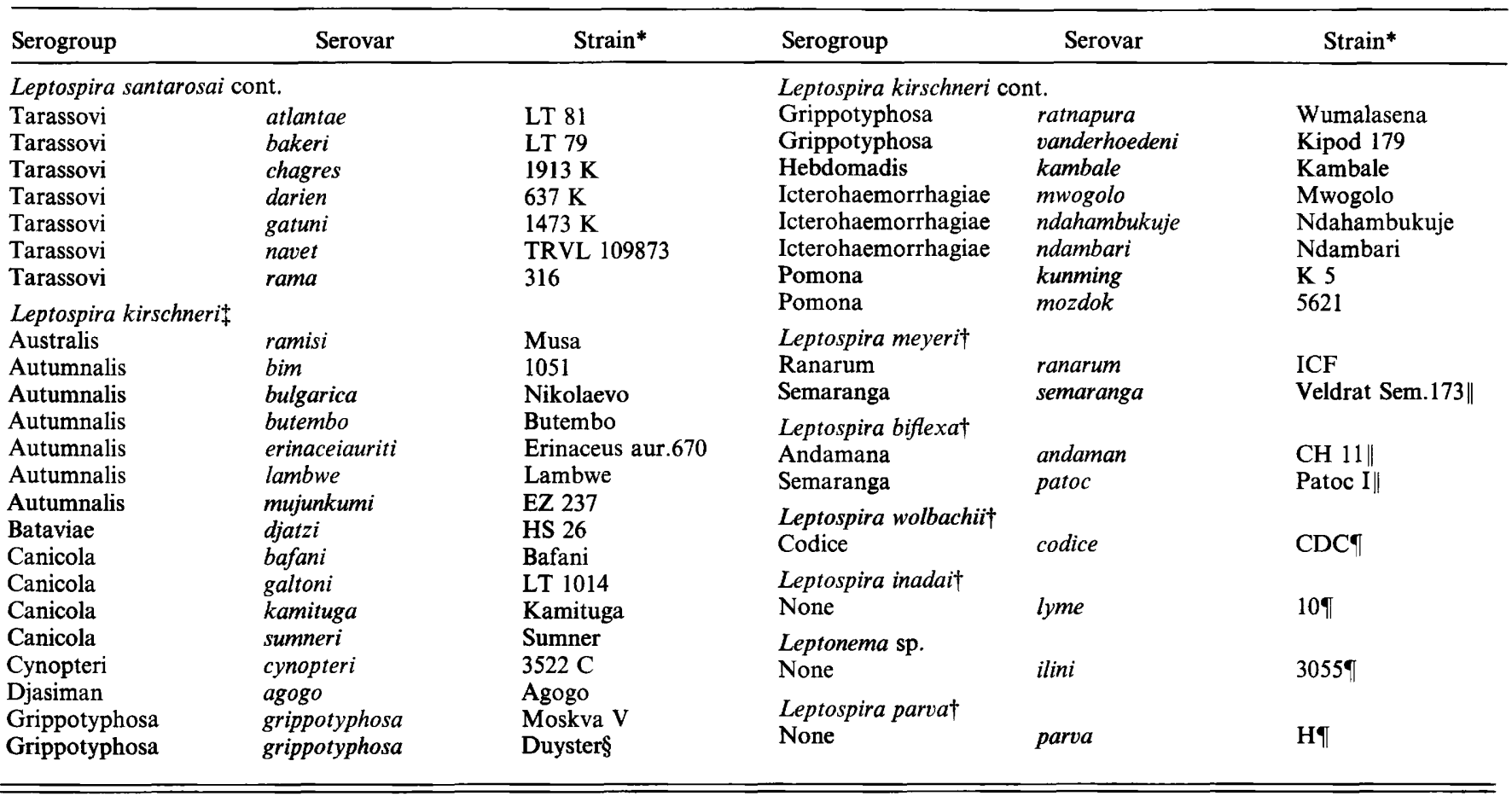

*All strains listed are reference strains except the strain indicated by $\S$ which is a Dutch clinical isolate.

$\dagger$ Species according to Yasuda et al. (1987) and extended by A. F. Kaufmann (personal communication).

† Serovars listed according to unofficially named $L$. alstoni (A. F. Kaufmann, personal communication). L. alstoni was replaced by $L$. kirschneri (Ramadass et al., 1992).

\| Non-pathogenic leptospires according to the Subcommittee on the Taxonomy of Leptospira.

These strains are not leptospires according to the Subcommittee on the Taxonomy of Leptospira.

for the detection of leptospires provided that these micro-organisms are present in relatively large numbers. With the introduction of PCR, rapid detection of small numbers of leptospires in clinical samples may become practical due to specific amplification of leptospiral DNA. Thus far, PCR has been applied to study genetic disorders but also to detect viral and bacterial infections (Demmler et al., 1988; Gerritsen et al., 1991; Hartskeerl et al., 1989; Hookey et al., 1992; Kogan et al., 1987; Kolk et al., 1992; Merien et al., 1992; Ou et al., 1988; Saiki et al., 1988; de Wit et al., 1991). In 1989, we developed a primer set and probes for the detection of Hardjobovis (serovar hardjo) in cattle urine by PCR (van Eys et al., 1989). In this study we describe the selection and construction of primer sets for the specific amplification of DNA of pathogenic leptospires and we present the DNA sequence analysis of PCR products from various leptospiral strains. To explore the potential of the PCR as a tool for early diagnosis of leptospirosis, we applied this method to sera of patients with proven leptospirosis aiming at the detection of leptospires in blood during the first 10 days of disease, i.e. largely the period between the onset of symptoms and the appearance of antibodies.

\section{Methods}

Strains and plasmids. Leptospiral strains used in this study were from our Reference Collection of Leptospira (Table 1), Other microorganisms used were Borrelia burgdorferi, Treponema reiteri, Mycobacterium spp., Klebsiella pneumoniae, Streptococcus pneumoniae, Salmonella sp. group B, Neisseria gonorrhoeae, Pseudomonas aeruginosa, Yersinia enterocolytica and Escherichia coli (kindly provided by Dr R. J. van Ketel, Department of Medical Microbiology, Academic Medical Hospital, Amsterdam, The Netherlands). E. coli strain DH5 $\alpha$ (Hanahan \& Meselson, 1983) was used as a host for plasmid pUC19 (Yanisch-Perron et al., 1985) and derivatives.

Culture media and reagents. Leptospires were cultured in EMJH medium as described by Johnson \& Harris (1967). E. coli DH5 $\alpha$ was grown either in LB medium or in SOB medium (Sambrook et al., 1989). When appropriate, ampicillin, IPTG, X-gal and Difco agar (1.5\%, $\mathrm{w} / \mathrm{v}$ ) were added to the LB medium (Sambrook et al., 1989). Guanidinium thiocyanate (GuSCN) was from Fluka. Diatoms (high purity, analytical grade kieselguhr DG) were obtained from Riedel-de Haën.

Restriction enzymes and T4 DNA ligase were purchased from Boehringer. Heat-stable Taq DNA polymerase was from Perkin-Elmer Cetus. Solutions of deoxynucleotides dATP, dTTP, dCTP, dGTP $(100 \mathrm{~mm}, \mathrm{pH} 7.5)$ and dUTP (200 mM, pH 7.5) were from Pharmacia.

Collection of clinical samples and culture. All paired blood samples used in this study were from 79 leptospirosis patients in The Netherlands and on Barbados. Forty samples from patients suspected 
(a) e1

5. CroAatcecr omptaAMAGT AAGCAAAGA ' GACTTAGCGA CATATTTTCA TTCGTTTCTT ATGTTAATTT CGCCATATTT AATGCTTTAT AAATAACGCA TGATACCAAA TCTGAGAGAC TGGATTAAAA AAATCCATAA TCACTGCCCA TTTATTGCGT ACTATGGTTT AGACTCTCTG ACCTAATTTT TTTAGGTATT AGTGACGGGT

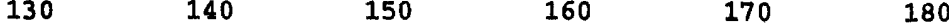
TCCAGCCCAT TCTTGACTAC TATTAGATAA CCATtGaATA ATCGTCTGAg gaAataAAAT AGGTCGGGTA AGAACTGATG ATAATCTATT GGTAACTTAT TAGCAGACTC CT"TTATTTTA $\begin{array}{llllll}190 & 200 & 210 & 220 & 230 & 240\end{array}$ CAAAGACGAA GCAAAAATGA TCGGCATCAC GTTCGCGCCG TTTACTTTGA AAGGAATAGA GTTTCTGCTT CGTTTTTACT AGCCGTAGTG CAAGCGCGGC AAATGAAACT TTCCTTATCT TTGACTCTTG GCCTGAACCA TTTTTCTTCC GACCATTTGT TTTCC 3' AACTGAGAAC CGGACTTGGT AAAAAGAAGG CTGGTAAACA AAAGG 5 .

(b) B64-I

G2

30

40

50

60

ACTAACTGAC AAACTHCYAC TTGGATCTGT TGTCTATCTT CTTCGGTATA AATACCGTTG

3. TGATTGACTC TTTGAAGATG AACCTAGACA ACAGATAGAA GAAGCCATAT TTATGGCAAC

GCAGCTTGGA CAGCCAGAAC CCGGATTCTC TGAACGATCT CATGAGTTTC CTGGAGATAT CGTCGAACCT GTCGGTCTTG GGCCTAAGAG ACTTGCTAGA GTACTCAAAG GACCTCTATA $\begin{array}{llllll}130 & 140 & 150 & 160 & 170 & 180\end{array}$

CCTTCAGTAG TCTGGATTAG AGACATACCA TCTTCAGTGT TCATTTCCGC TCTTCTGAGA GGAAGTCATC AGACCTAATC TCTGTATGGT AGAAGTCACA AGTAAAGGCG AGAAGACTCT CCCAGAATCT GAGTTCTCAT CTTTTCGGAC ACTGCAAGAC CGGAAGCATC ATCGCCTGCG GGGTCTTAGA CTCAAGAGTA GAAAAGCCTG TGACGTTCTG GCCTTCGTAG TAGCGGACGC

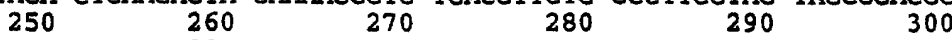

CGGTTGATTC TCATTCCGGA GGACAATTTC TCAATGTCCT TACCCATGTT TTCGCTGTTG

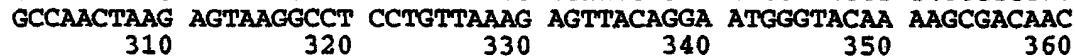
AACTTCAACG TTCTGTGCGC GAAAATGGCA CTGATATTAT GGTTGATAAT CATTCGGTTC TTGAAGTTGC AAGACACGCG CTTTTACCGT GACTATAATA CCAACTATTA GTAAGCCAAG

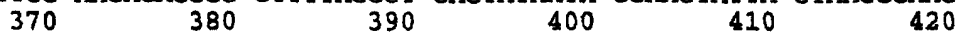
CTCCTTGAAT CCGATTCCCT GAAATTAGGG GATTATGATT TTTCAAAGGT CTTCCTTGAC GAGGAACTTA GGCTAAGGGA CTTTAATCCC CTAATACTAA AAAGTTTCCA GAAGGAACTG

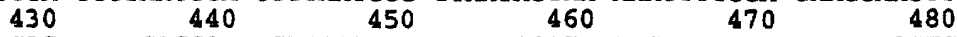
CTTTTCAGAG AATGCATCGA CGATTGCATA CATTCCGATA ATGAACTTTT TTAGAAATTC GAAAAGTCTC TTACGTAGCT GCTAACGTAT GTAAGGCTAT TACTTGAAAA AATCTTTAAG $490 \quad 500 \quad 510 \quad 520 \quad 530 \quad 50$ AGAGATAAAA ATCGTCTTCC TAAACTAGAA TATCTATGTC CCTTCTGAGA TATTTCTTTT TCTCTATTTT TAGCAGAAGG ATTTGATCTT ATAGATACAG GGAAGACTCT ATAAAGAAAA 550 560

TTATCATAGG TTCGACTTAA GGA 3'

AATACEATCC AAGCTEAMTY CCT 5 .

B64-II
Fig. 1. (a) Nucleotide sequence of the DNA insert of recombinant plasmid pLIPs60. The positions of primers $\mathrm{G} 1$ and $\mathrm{G} 2$ are indicated. (b) Nucleotide sequence of the DNA insert of recombinant plasmid pBIM64. The positions of primers B64-I and B64-II are indicated. of leptospirosis but serologically negative, and 40 samples from healthy individuals were used as negative control sera. Blood was clotted at room temperature and serum frozen at $-20^{\circ} \mathrm{C}$. Sera from 60 patients and 40 negative control sera had been collected several years before PCR was applied. These sera were kept for several weeks at $4{ }^{\circ} \mathrm{C}$ for serology and later frozen at $-20^{\circ} \mathrm{C}$. The sera of the other 19 patients and 40 negative control sera collected over the last 2 years were directly frozen at $-20^{\circ} \mathrm{C}$ after blood was drawn. First samples of leptospirosis patients were collected before the 10th day after onset of the disease, and second samples at least 1 week later. First as well as second samples were examined serologically. A few drops of whole blood of first samples were inoculated directly after collection into EMJH medium for culturing.

In preliminary experiments we found that red blood cells inhibited PCR. The maximum volume of whole blood which could be processed without severe inhibition of the PCR was $100 \mu \mathrm{l}$, whereas $1-3 \mathrm{ml}$ serum could be used without any problems. The PCR assay on serum gives much better results than on whole blood samples, inspite of possible loss of leptospires trapped in blood clots. Therefore, PCR was performed on $1 \mathrm{ml}$ serum of the first sample instead of blood.

Serology. To establish a titre rise or seroconversion the microscopic agglutination test (MAT) was applied according to standard method- ology (Dikken \& Kmety, 1978). A battery of live leptospiral strains recommended by Faine (1982) was used as antigens in this test. ELISA was performed as described previously (Terpstra et al., 1980). Strain Wijnberg (serovar copenhageni) and strain Hardjoprajitno (serovar hardjo) were used as antigens in ELISA. High IgM levels against leptospires were considered indicative of current or recent infection.

Identification of strains. The strains isolated from humans were typed by the cross-agglutination absorption test (CAAT) (Dikken \& Kmety, 1978), and by use of monoclonal antibodies in agglutination tests (Korver et al., 1988; Terpstra et al., 1987).

DNA technology. Standard procedures were used for DNA preparation, restriction enzyme digestion, ligation, and transformation (Sambrook et al., 1989). DNA fragments were sequenced using an automated sequencing apparatus and the sequencing kit of Applied Biosystems according to the instructions of the manufacturer. DNA sequence data were processed using the PC/GENE 6.6 software (IntelliGenetics). Preparation of ${ }^{32} \mathrm{P}$-labelled DNA probes was done with a random priming labelling kit (Boehringer). Southern blotting (Southern, 1975) and hybridization with ${ }^{32} \mathrm{P}$-labelled DNA probes were performed according to standard procedures (Sambrook et al., 1989). Non-radioactive probes were made using a DNA digoxygenin-dUTP 
labelling and detection kit (Boehringer), and hybridization was done as described by Hartskeerl et al. (1989). Hybridization and washing steps were done at $68^{\circ} \mathrm{C}$ (high stringency) or at $55^{\circ} \mathrm{C}$ (low stringency).

Construction of genomic DNA libraries. Construction of a genomic DNA library of $L$. interrogans strain RGA has been described previously (van Eys et al., 1991). To construct a genomic DNA library of $L$. kirschneri strain 1051, EcoRI-digested genomic DNA was ligated into pUC19. $E$. coli strain DH5 $\alpha$ was used for transformation.

Purification of DNA from clinical specimens. DNA was extracted according to Boom et al. (1990) with minor modifications (Gravekamp et al., 1991). Serum (1 ml) was mixed with 9 vols of a GuSCN-lysis buffer $(120 \mathrm{~g} \mathrm{GuSCN}, 100 \mathrm{ml} 0.1 \mathrm{M}$-Tris $/ \mathrm{HCl}, \mathrm{pH} 6.4,22 \mathrm{ml} 0.2 \mathrm{M}-$ EDTA, and $2.6 \mathrm{ml}$ Triton $\mathrm{X}-100$ ). Subsequently, $40 \mu \mathrm{l}$ of a suspension of diatoms ( $10 \mathrm{~g}$ diatoms, $50 \mathrm{ml}$ distilled water, and $500 \mu \mathrm{l} 32 \%$, w/v, $\mathrm{HCl})$ was added and the mixtures were thoroughly vortexed. The diatoms complexed with DNA were rapidly sedimented by centrifugation, washed twice with a GuSCN-containing washing-buffer (120 g GuSCN, and $100 \mathrm{ml} 0.1 \mathrm{M}$-Tris $/ \mathrm{HCl}$, pH 6.4), twice with $70 \%$ (v/v) ethanol, and once with acetone, and finally dried at $56{ }^{\circ} \mathrm{C}$ for $10 \mathrm{~min}$. DNA was eluted from the diatoms by incubation in distilled water for $10 \mathrm{~min}$ at $56^{\circ} \mathrm{C}$ and subsequently treated with proteinase $\mathrm{K}$ ( $250 \mu \mathrm{g} \mathrm{ml}^{-1}$ final concentration) for $10 \mathrm{~min}$. Finally, proteinase $\mathrm{K}$ was inactivated by incubation at $100^{\circ} \mathrm{C}$ for $10 \mathrm{~min}$.

PCR. Primers G1 (5' CTG AAT CGC TGT ATA AAA GT) and G2 (5' GGA AAA CAA ATG GTC GGA AG) were derived from the 5 end (nucleotides 1-20) and the $3^{\prime}$ end (nucleotides 264-285), respectively, of the sequence of the recombinant plasmid pLIPs60 shown in Fig. $1(a)$. Primers B64-I ( $5^{\prime}$ CTG AAT TCT CAT CTC AAC TC) and B64-II (5' GCA GAA ATC AGA TGG ACG AT) were derived from the $5^{\prime}$ end (nucleotides 1-20) and the $3^{\prime}$ end (nucleotides 542-563), respectively, of the sequence of recombinant plasmid pBIM64 presented in Fig. 1(b).

PCR was performed as described previously (van Eys et al., 1989) with minor modifications. Briefly, $40 \mu$ of DNA samples were mixed with $5 \mu \mathrm{l}$ of the reaction buffer $(10 \times$ buffer: $500 \mathrm{mM}-\mathrm{KCl}, 20 \mathrm{mM}$ $\mathrm{MgCl}_{2}, 100 \mathrm{mM}$-Tris/ $\mathrm{HCl}, \mathrm{pH} \mathrm{9.0,} \mathrm{and} 10 \mu \mathrm{g}$ gelatin $\mathrm{ml}^{-1}$ ), $0.5 \mu \mathrm{l}$ of a 100 pM solution of each primer, $0.5 \mu \mathrm{l}$ of a mixture containing $25 \mathrm{~mm}$ of each of the four deoxynucleotides dATP, dTTP, dCTP and dGTP, $0.1 \mu \mathrm{l} \mathrm{Taq}$ polymerase $(0.5 \mathrm{U})$ and $3.4 \mu \mathrm{l}$ distilled water to a final volume of $50 \mu \mathrm{l}$. DNA amplification reactions were performed in a Pharmacia LKB Gene ATAQ controller using 32 cycles. One amplification cycle consisted of denaturation of the DNA for $90 \mathrm{~s}$ at $94^{\circ} \mathrm{C}$, annealing of the primers for $60 \mathrm{~s}$ at $55^{\circ} \mathrm{C}$ and elongation for $120 \mathrm{~s}$ at $72^{\circ} \mathrm{C}$.

To prevent false-positive reactions by contaminating PCR products from earlier experiments, dUTP was incorporated and PCR mixtures were treated with uracil- $N$-glucosylase to degrade contaminating PCR products as described by Persing (1991). Furthermore, rooms and equipment were decontaminated with Chlorox according to Prince \& Andrus (1992).

\section{Results}

\section{Screening of DNA libraries and selection of primers}

Clone pLIPs60 was selected from the genomic DNA library of $L$. interrogans strain RGA on the basis of a strong hybridization signal with DNA from most Leptospira species as described previously (van Eys et al., 1991). This clone reacted to representatives of all pathogenic Leptospira species according to Yasuda et al. (1987) with the exception of L. kirschneri. The nucleotide sequence of pLIPs60 was determined (Fig. $1 a$ ) and used for the selection of primers G1 and G2.

Species L. kirschneri comprises important pathogenic leptospiral strains. To design a PCR assay that included the detection of leptospiral strains of this species, a second genomic DNA library was made of L. kirschneri strain 1051. Six selected recombinant clones, containing inserts of $200-600 \mathrm{bp}$, were further characterized. Specificity of the clones was tested by Southern blot analysis with EcoRI-digested genomic DNA from serovar icterohaemorrhagiae of species $L$. interrogans, serovar hardjo of species $L$. borgpetersenii, and serovars bim, mozdok, mwogolo and grippotyphosa all belonging to species $L$. kirschneri. Two recombinant plasmids, pBIM12 and pBIM64, gave a strong hybridization signal with a DNA fragment of about $600 \mathrm{bp}$ from serovars of species $L$. kirschneri only (data not shown). The nucleotide sequence of these two recombinants was determined. The nucleotide sequence of pBIM64 (Fig. $1 b$ ) was used for the selection of primers B64-I and B64-II.

We have tested a large number of reference strains belonging to all pathogenic and non-pathogenic Leptospira species as mentioned in Table 1. Strains of all pathogenic Leptospira species except L. kirschneri (Table 1) were amplified by primers G1 and G2, as expected on the basis of hybridization experiments with plasmid pLIPs60. DNA from strains of the pathogenic species $L$. kirschneri only (Table 1) was amplified by primer set B64-I/B64-II which is in agreement with the hybridization experiments with plasmid pBIM64. The detection level of both PCRs was estimated to be 1-10 leptospires in $1 \mathrm{ml}$ spiked serum (Gravekamp et al., 1991). The combined primer sets G1/G2 and B64-I/B64-II amplified DNA by PCR from all pathogenic Leptospira species, i.e. strains of $L$. interrogans, $L$. borgpetersenii, $L$. weilii, L. noguchii, L. santarosai and L. meyeri strain ICF were amplified by $G 1$ and $G 2$, whereas strains of $L$. kirschneri were amplified by B64-I and B64-II. Representative examples of PCR results from all these pathogenic species and one non-pathogenic species, $L$. biflexa strain Patoc I, using the mixed primer sets are shown in Fig. 2(a). As compared to the results obtained with the PCRs using the distinct primer sets G1/G2 and B64-I/B64-II, no mutual interference reactions were observed when PCR was performed with a mixture of these primer sets (data not shown).

Amplification of DNA from $L$. inadai strain 10 and $L$. meyeri strain Veldrat Semarang 173 gave PCR products of the correct size. These PCR products did not hybridize with probes derived from the seven pathogenic species in this study (data not shown). The combined primer sets 


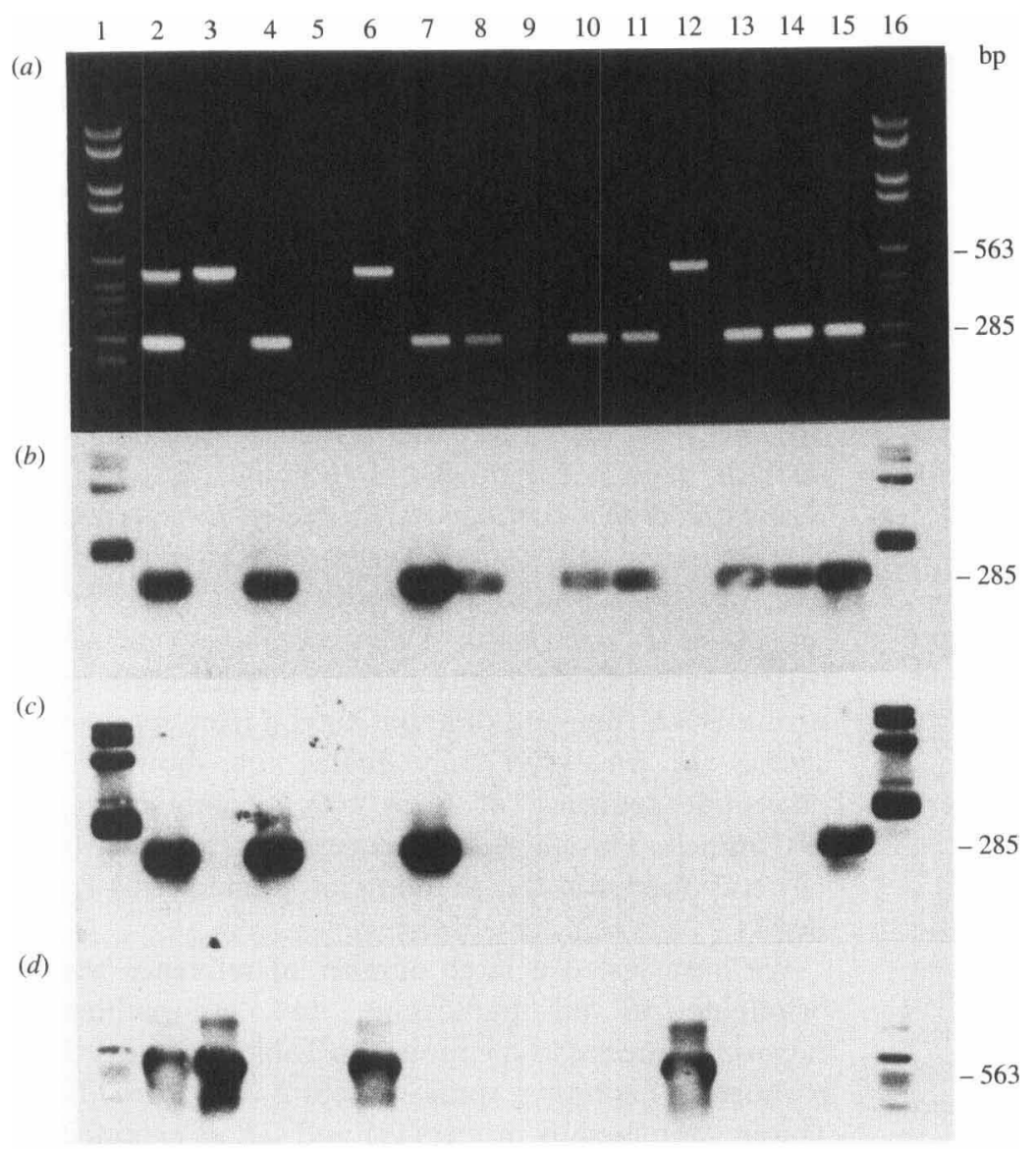

Fig. 2. (a) Agarose gel (2\%) showing PCR products of various strains from pathogenic and non-pathogenic Leptospira species using primers G1/G2 and B64-I/B64-II. Lanes: 1, molecular mass markers; 2, mixture of DNA from $L$. interrogans strain M20 and L. kirschneri strain 1051 (positive controls); 3, DNA from $L$. kirschneri strain 1051 (positive control); 4, DNA from $L$. interrogans strain M20 (positive control); 5, empty; 6, L. kirschneri strain Duyster; 7, L. interrogans strain $\mathrm{M} 20 ; 8$, L. meyeri strain ICF; 9 , L. biflexa strain Patoc I; 10, L. santarosai strain TRVL 34056; 11, L. weilii strain Celledoni; 12, L. kirschneri strain $1051 ; 13$, L. noguchii strain $1161 \mathrm{U} ; 14$, L. borgpetersenii strain Mus 127; 15, L. interrogans strain Jez Bratislava; and 16, molecular mass markers. DNA fragments of $285 \mathrm{bp}$ are $P C R$ products generated with $\mathrm{G} 1 / \mathrm{G} 2$ primers, $563 \mathrm{bp}$ fragments are PCR products generated with B64-I/B64-II primers. Hybridization with an amplicon DNA probe derived from strain Wijnberg under low $(b)$ and high $(c)$ stringency conditions and from strain 1051 under high stringency conditions $(d)$ with PCR products of various members (see Fig. $2 a$ ) of pathogenic and non-pathogenic Leptospira species. did not result in a detectable amplification of DNA from L. wolbachii, L. parva and Leptonema illini and from other microbiological sources (data not shown).

\section{Specificity of the probes}

To study DNA polymorphism in the region spanned by primers G1 and G2 of the various Leptospira species hybridization experiments were performed under high and low stringency conditions. The G1/G2-generated PCR product from $L$. interrogans strain Wijnberg, when used as probe, hybridized well to G1/G2-generated PCR products from genomic DNA of all pathogenic Leptospira species, except $L$. kirschneri, in a Southern blot performed under conditions of low stringency (Fig. $2 b$ ). In contrast to the low stringency conditions, Southern blot hybridizations done under high stringency conditions gave strong bands with PCR products generated from members of the species $L$. interrogans only: serovars icterohaemorrhagiae, copenhageni and bratislava (Fig. 2c). Although the nucleotide sequences corresponding to primers $\mathrm{G} 1$ and $\mathrm{G} 2$ are highly conserved, the DNA region spanned by these primers apparently shows polymorphism between various Leptospira species.

As expected, the B64-I/B64-II-generated amplicon probe derived from DNA of serovar bim hybridized only to PCR products from serovars bim and grippotyphosa (Fig. $2 d$ ), which both belong to species $L$. kirschneri.

\section{Inter-species DNA polymorphism}

To investigate further the DNA polymorphisms as revealed by the hybridization experiments under different stringency conditions, the DNA sequence of regions between $\mathrm{G} 1$ and $\mathrm{G} 2$ was determined for all pathogenic species. Representative DNA sequences are shown as a multiple alignment in Fig. 3. We determined the homology between the various sequences flanked by $\mathrm{G} 1$ and $\mathrm{G} 2$ and the corresponding sequence of $L$. interrogans strain RGA. In accordance with the results obtained from the Southern blotting analysis, we found that sequences of members of species $L$. interrogans showed a high degree of homology (98-100\%) with the sequence of strain RGA. The homology between sequences of other Leptospira species and that of strain RGA was clearly less, i.e. $65-90 \%$. 


\section{M20}

Jez Bratislava

TRVL 34056

Celledoni

Mus 127

$1161 \mathrm{U}$

ICF

M20

Jez Bratislava

Celledoni

Mus 127

$1161 \mathrm{U}$

ICF

M20

AAATCCATAATCACTGCCCATCCAGCCCATTCTTGACTACTATTAGATAA Jez Bratislava AAATCCATAATCACTGCCCATCCAGCCCATTCTTGACTACTATTAGATAA TRVL 34056 AAGTCCATAATGATCGCCCAACCCGCCCACTGTTCGCTGCTGGAAGACAA Celledoni AAGTCCATAATGATCGCCCAACCGGCCCACTGTTCGCTGCTGGAAGACAA Mus 127 AAGTCCATAATGATCGCCCAACCCGCCCATTGTTCGCTACTGGAAGACAA $1161 \mathrm{U}$ AAATCCATAATCACTGCCCATCCAGCCCATTCTTGACTACTATTGGATAA ICF AAGTCCATAATCACGGCCCAACCCGCCCATTCCTGACTGCTATTGGACAA

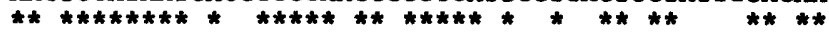

M20 CCATTGAATAATCGTCTGAGGAAATAAAATCAAAGACGAAGCAAAAATGA Jez Bratislava CCATTGAATAATCGTCTGAGGAAATAAAATCAAAGACGAAGCAAAAATGA TRVL 34056 CCACTGAATGATCGTCTGTGGGAACAGGATCAAGGAAGAAGCAAAGATGA Celledoni CCACTGAATGATCGTCTGCGGAAACAAGATCAAAGAAGAAGCAAAAATAA Mus 127 CCACTGAATGATCGTCTGTGGAAACAGGATCAAGGACGAAGCAAAGATGA $1161 \mathrm{U}$ CCATTGAATAATCGTTTGTGGAAACAAAATTAAAGAAGAAGCAAAGATGA ICF CCACTGGATGATCGTCTGTGGAAACAAAATCAAAGAAGAAGCAAAGATGA

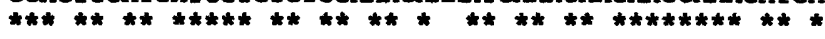

M20 TCGGCATCACGTTCGCGCCGTTTACTTTGAAAGGAATAGATTGACTCTTG Jez Bratislava TCGGCATCACGTTCGCACCATTTACTTTGAAAGGAATAGATTGACTCTTG TRVL 34056 TCGGCATTACGTTCGCGCCGTTCACTTTAAAAGGAATGGATTGGCTTTTC Celledoni TCGGCATTACGTTTGCGCCGTTTACTTPAAAAGGAATGGATTGGCTTTTC Mus 127 TCGGCATTACGTTTGCGCCATTTACTTTAAAAGGAATAGATTGGCTTTTC $1161 \mathrm{U}$ TCGGCATCACGTTAGCACCOTTTACTTTGAAAGGAATCGATTGGCTTTTT ICF TCGGCATAACGTTCGCGCCETTPACTTTGAAAGGGATGGACTTGCTTTTC

M20 GCCTGAACCATTTTTCTTCCGACCATTTGTTTTCC Jez Bratislava GCCTGAACCATTTTTCTTCCGACCATTTGTTTTCC TRVL 34056 GCCTGAACCATTTTTCTTCCGACCATTTGTTTTCC Celledoni GCCTGAACCATTTTTCTTCCGACCATTTGTTTTCC Mus 127 GCCTGAACCATTTTTCTTCCGACCATTTGTTTTCC $1161 \mathrm{U}$ GCTTGAACCATCTTTCTTCCGACCATTTGTTTTCC ICF GCCTGCACCATTWTTCTTCCGACCATTTGTTMTCC

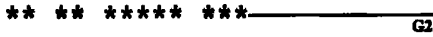

$(99.68)$

$(98.47)$

$(79.68)$

$(80.8 \%)$

$(90.28)$

$(82.48)$
Table 2. Comparison of $P C R$ with cultures

Culture was performed on blood and PCR on serum (see Methods). All sera were tested two or more times by PCR and gave reproducible results. PCR positive, DNA bands were visible on Southern blots. No DNA bands were visible on Southern blots in 80 negative controls (40 samples from patients without leptospirosis and 40 samples from healthy individuals).

\begin{tabular}{lccc}
\hline & PCR positive & PCR negative & Total \\
\hline Culture positive & 20 & 8 & 28 \\
Culture negative & 19 & 32 & 51 \\
Total & 39 & 40 & 79 \\
\hline
\end{tabular}

\section{$P C R$ on serum samples}

Table 2 shows that PCR $(50 \% ; 39 / 79)$ was more often positive than culturing $(35 \% ; 28 / 79)$ on samples from proven leptospirosis patients. Still both methods failed in
Fig. 3. Multiple sequence alignment of PCR products obtained with primer set $\mathrm{G} 1 / \mathrm{G} 2$ from members of all pathogenic species, with the exception of $L$. kirschneri which was not amplified by $\mathrm{G} 1 / \mathrm{G} 2 . \quad L$. interrogans strain M20; $L$. interrogans strain Jez Bratislava; L. santarosai strain TRVL 34056; $L$. weilii strain Celledoni; $L$. borgpetersenii strain Mus $127 ;$ L. noguchii strain $1161 \mathrm{U} ; L$. meyeri strain ICF. As indicated, sequences at the $5^{\prime}$ end (nucleotides 1-20) and the 3 ' end (nucleotides 266-285) correspond to the primers G1 and G2, respectively. Percentages of homology between the sequences flanked by $\mathrm{G} 1$ and $\mathrm{G} 2$ and the corresponding sequence of $L$. interrogans strain RGA, as depicted in Fig. 1(a), are shown in parentheses. Asterisks are used to show that a position in the alignment is perfectly conserved. more than one-third $(40 \% ; 32 / 79)$ of the cases and there was a considerable discrepancy between results of both methods. About $70 \%(20 / 28)$ of the serum samples from which icterohaemorrhagiae/copenhageni, bim or grippotyphosa could be isolated by culturing was positive by PCR (Table 3). We demonstrated the presence of leptospires by PCR at a comparable rate of about $60 \%$ (16-27) of the samples from patients infected with icterohaemorrhagiae/copenhageni or hardjo from which no leptospires could be cultured. For culturally negative serum samples from patients with a grippotyphosa infection or pomona infection, this rate was $12 \%(3 / 24)$. All leptospirosis patients showed high IgM levels by ELISA and a titre rise or seroconversion in MAT in second samples (results not shown). Forty sera from patients without leptospirosis and 40 sera from healthy individuals used as a negative control gave negative results by PCR and Southern blotting. 
Table 3. Comparison of PCR with cultures

\begin{tabular}{|c|c|c|c|}
\hline Serovar & Species & $\begin{array}{l}\text { PCR positive/ } \\
\text { culture positive }\end{array}$ & $\begin{array}{l}\text { PCR positive/ } \\
\text { culture negative }\end{array}$ \\
\hline icterohaemorrhagiae/copenhageni & L. interrogans & $9 / 12$ & $8 / 12$ \\
\hline hardjo & L. borgpetersenii & $0 / 0$ & $8 / 15$ \\
\hline grippotyphosa & L. kirschneri & $3 / 4$ & $2 / 16$ \\
\hline bim & L. kirschneri & $8 / 12$ & $0 / 0$ \\
\hline pomona & L. interrogans & $0 / 0$ & $1 / 8$ \\
\hline
\end{tabular}

\section{Discussion}

In this study amplification by PCR of DNA from practically all reference strains of all presently recognized pathogenic Leptospira species was evaluated. A PCR using two sets of primers, G1/G2 and B64-I/B64-II, amplified DNA from serovars belonging to all pathogenic Leptospira species as described by Yasuda et al. (1987) and Ramadass et al. (1992). Our results do not concur completely with those obtained by PCR performed on the DNA sequence of the 16S rRNA gene (Hookey, 1992). Hookey (1992) found PCR products of the correct size from DNA of both strains ICF and Veldrat Semarang 173 of L. meyeri, described as a nonpathogenic species (Yasuda et al., 1987). We found an anomalous PCR product from strain Veldrat Semarang 173, whereas strain ICF gave a PCR product of the correct size which hybridized well with pathogenicLeptospira-specific probes. Therefore, the designation by Yasuda et al. (1987) of all strains of species L. meyeri to a non-pathogenic status is questionable. Our results and also those described by Segers et al. (1991) were in accordance with the classification of both strains by the International Committee on Systematic Bacteriology, Subcommittee on Taxonomy of Leptospira, which consider strain ICF as pathogenic and strain Veldrat Semarang 173 as non-pathogenic. In the case of strain 10, the only strain of species $L$. inadai, we found an anomolous PCR product, whereas Hookey (1992) found a PCR product of the correct size. $L$. inadai strain 10 was reported by Yasuda et al. (1987) as a pathogenic Leptospira species. However, our result suggests the need for further investigation. The anomalous PCR products of strain Veldrat Semarang 173 and strain 10 are probably due to mispriming events. They do not interfere with the specific detection of DNA from pathogenic leptospires in clinical serum samples because they do not hybridize with the Leptospira-specific probes. The $16 \mathrm{~S}$ rRNA gene is highly conserved. Primers derived from this gene in pathogenic leptospires may still amplify in
PCR DNA of other micro-organisms such as E. coli and Actinomyces pyogenes (Wagenaar et al., 1991) or nonpathogenic $L$. biflexa Patoc I (Merien et al., 1992).

Inter-species DNA polymorphisms within the genus Leptospira have been demonstrated by Yasuda et al. (1987), Ramadass et al. (1992) and Herrmann et al. (1992). Our results obtained by PCR, hybridization and DNA sequencing give further and more detailed evidence of polymorphism such as observed between ICF and Veldrat Semarang 173.

The results obtained by PCR applied on clinical samples depend greatly on the purity of the extracted target DNA. The presence of inhibitory factors in serum samples which impede amplification reactions have to be taken into account. Extraction of DNA using diatom/ GuSCN as described by Boom et al. (1990) has been demonstrated to result in a sensitivity of 1-10 leptospires (ml spiked serum samples) ${ }^{-1}$ (Gravekamp et al., 1991). These results correspond fairly well to those described by Burstain et al. (1991) and Hay et al. (1990) who detected 1-10 treponemes $(50 \mu \mathrm{l})^{-1}$ by PCR, and Noordhoek (1991) who detected 100 treponemes in $1 \mathrm{ml}$ cerebrospinal fluid by PCR.

In this study we have shown the practical value of the PCR for the early diagnosis of leptospirosis when we extracted DNA from serum of patients infected by prevalent serovars in The Netherlands and Barbados with the diatoms/GuSCN method. Comparison of results obtained by PCR to those obtained by culturing indicates that PCR is more sensitive. Failure of leptospires to grow in culture is generally observed and may, at least partly, be attributed to fastidiousness of leptospires. It is not clear why PCR failed in the detection of leptospiral DNA in some sera of proven patients. This failure is possibly due to the fact that most of sera used in this study had been stored for considerable time at $4^{\circ} \mathrm{C}$, and subsequently on several occasions frozen and thawed which may have led to DNA degradation. In addition, PCR may fail when leptospires are present in very low numbers below the detection level 
of 1-10 leptospires $\mathrm{ml}^{-1}$. It is remarkable that in severe infections with icterohaemorrhagiae/copenhageni and bim both PCR and culture were more often positive than in generally mild infections such as pomona, hardjo and grippotyphosa. We postulate that a lower number of leptospires in the blood of patients with mild infections is a cause of lower yields by both PCR and culture. Testing larger volumes of sera may yield a higher positive score by PCR. The cause or causes of PCR failures on serum from proven patients need to be clarified and, if possible, removed.

As reported by Persing (1991), the occurrence of false positive PCR results is caused rather by contamination with amplified DNA than by contamination with target DNA. In accordance with this report, we found that all negative control sera, collected in the same period as the patients' sera, were negative by PCR.

We conclude that PCR is a promising method for the quick and early detection of leptospires in clinical samples in the period between the first appearance of clinical symptoms and when antibodies become detectable. This study is complementary to our earlier studies on urine (van Eys et al., 1989) and studies on urine by others (Gerritsen et al., 1991; Merien et al., 1992), and studies on plasma and cerebrospinal fluid (Merien et al., 1992). The DNA polymorphism in PCR products deserves to be explored for the identification of causative species or even strains.

This work was supported financially by EEC grant TS2-00113-NL. We thank Professor Dr J. Goudsmit for providing the automated sequencing apparatus, Mrs E. Baan for skilful assistance, and Dr R. J. van Ketel for providing the micro-organisms.

\section{References}

Boom, R., Sol, C. J. A., Salimans, M. M. M., Jansen, C. L., Wertheim-van Dillen, P. M. E. \& van der NoordaA, J. (1990). Rapid and simple method for purification of nucleic acids. Journal of Clinical Microbiology 28, 495-503.

Burstain, J. M., Grimpel, E., Lukehart, S. A., Norgard, M. V. \& RADOLF, J. D. (1991). Sensitive detection of Treponema pallidum by using the polymerase chain reaction. Journal of Clinical Microbiology 29, 62-69.

Centers for Disease ConTrol (1981). Annual Summary 1981: reported morbidity and mortality in the United States. Morbidity and Mortality Weekly Report 30, 1-134.

Demmler, G. J., Buffone, J., Schimbor, C. M. \& May, R. A. (1988). Detection of cytomegalovirus in urine from newborn by using polymerase chain reaction DNA amplification. Journal of Infectious Diseases 158, 1177-1185.

DikKen, H. \& KMETY, E. (1978). Serological typing methods of leptospirosis. Methods in Microbiology 11, 259-293.

van Eys, G. J. J. M., Gravekamp, C., Gerritsen, M. J., Quint, W., CORnelissen, M. T. E., TER SChegget, J. \& Terpstra, W. J. (1989). Detection of leptospires in urine by polymerase chain reaction. Journal of Clinical Microbiology 27, 2258-2262.

van Eys, G. J. J. M., Gerritsen, M. J., Korver, H., SChOONe, G. J., Kroon, C. C. M. \& Terpstra, W. J. (1991). Characterization of serovars of the genus Leptospira by DNA hybridization with Hardjobovis and Icterohaemorrhagiae probes with special attention to serogroup Sejroe. Journal of Clinical Microbiology 29, 1042-1048.
FAINE, S. (1982). In Guidelines for Control of Leptospirosis. WHO Offset Publications no. 67, pp. 67 and 77. Geneva: WHO.

Gerritsen, M. J., Olyhoek, T., Smits, M. A. \& Bokhout, B. A. (1991). Sample preparation method from polymerase chain reactionbased semiquantitative detection of Leptospira interrogans serovar hardjo serotype Hardjobovis in bovine urine. Journal of Clinical Microbiology 29, 2805-2808.

Gravekamp, C., van de Kemp, H., Carrington, D., van Eys, G. J. J. M., Everard, C. O. R. \& Terpstra, W. J. (1991). Detection of leptospiral DNA by PCR in serum from patients with copenhageniinfections. In Leptospirosis. Proceedings of the Leptospirosis Research Conference 1990, The 75th Anniversary of the Discovery of Causal Organism of Weil's Disease by Inada and Ido, pp. 151-164. Edited by Y. Kobayashi. Tokyo: University of Tokyo Press.

Hanahan, D. \& Meselson, M. (1983). Plasmid screening at high colony density. Methods in Enzymology 100, 333.

HARTSKeERL, R. A., DE WiT, M. Y. L. \& Klatser, P. R. (1989). Polymerase chain reaction for the detection of Mycobacterium leprae. Journal of General Microbiology 135, 2357-2364.

Hay, P. E., Clarke, J. R., Strugne, R. A., Taylor-Robinson, D. \& GoldHEIMER, D. (1990). Use of the polymerase chain reaction to detect DNA sequences specific to pathogenic treponemes in cerebral spinal fluid. FEMS Microbiology Letters 68, 428-432.

Herrmann, J. L., Bellinger, E., Perolat, P., Baranton, G. \& Saint Girons, I. (1992). Pulsed-field gel electrophoresis of NotI digests of leptospiral DNA: a new rapid method of serovar identification. Journal of Clinical Microbiology 30, 1696-1702.

HOOKEY, J. V. (1992). Detection of Leptospiraceae by amplification of 16S ribosomal DNA. FEMS Microbiology Letters 90, 267-274.

JoHnson, R. C. \& HARRIS, V. G. (1967). Differentiation of pathogenic and saprophytic leptospires. I. Growth at low temperature. Journal of Bacteriology 94, 27-31.

KMETY, E. \& DikKEN, H. (1988). International Committee on Systematic Bacteriology of the International Union of Microbiological Societies. Subcommittee on the Taxonomy of Leptospira. Revised list of Leptospira serovars I. Groningen: University Press.

Kogan, S. C., DoherTy, M. \& GitschIER, J. (1987). An improved method for prenatal diagnosis of genetic diseases by analysis of amplified DNA sequences. Application to hemophilia A. New England Journal of Medicine 317, 985-990.

Kolk, A. H. J., Schuitema, A. R. J., KutPers, S., van Leeuwen, J., Hermans, P. W. M., van Embden, J. D. A. \& Hartskeerl, R. A. (1992). Detection of Mycobacterium tuberculosis using polymerase chain reaction and a non-radioactive detection system. Journal of Clinical Microbiology 30, 2567-2575.

Korver, H., Kolk, A. H. J., Vingerhoed, J., van Leeuwen, J. \& TERPSTRA, W. J. (1988). Classification of the Icterohaemorrhagiae serogroup by monoclonal antibodies. Israelian Veterinary Medicine 44, 15-18.

Merien, F., Amourioux, P., Perolat, P., Baranton, G. \& Saint GIRoNs, I. (1992). Polymerase chain reaction for the detection of Leptospira spp. in clinical samples. Journal of Clinical Microbiology 30, 2219-2224.

NoORDHOEK, G. T. (1991). Syphilis and Yaws. A molecular study to detect and differentiate pathogenic treponemes. $\mathrm{PhD}$ thesis. University of Utrecht, The Netherlands.

Ou, C., Kwok, S., Mitchell, S. W., Mack, D. H., SNinsky, J. J., Krebs, J. W., Feorino, P., Warfield, D. \& Schochietman, G. (1988). DNA amplification for direct detection of HIV-I in DNA of peripheral blood mononuclear cells. Science 239, 295-297.

Persing, D. H. (1991). Polymerase chain reaction: trenches to benches. Journal of Clinical Microbiology 29, 1281-1285.

PRINCE, A. M. \& ANDRUS, L. (1992). PCR: how to kill unwanted DNA. Biotechniques 12, 358-360.

Ramadass, P., Jarvis, B. D. W., Corner, J., Penny, D. \& Marshall, R. B. (1992). Genetic characterization of pathogenic Leptospira species by DNA hybridization. International Journal of Systematic Bacteriology 42, 215-219.

Saiki, R. K., Gelfland, D. H., Stoffel, S., Scharf, S. J., Higuchi, R., Horn, G. T., Mullis, K. B. \& ERlich, H. A. (1988). Primerdirected enzyme amplification of DNA with a thermostable DNA polymerase. Science $239,487-491$. 
Sambrook, J., Fritsch, E. F. \& Maniatis, T. (1989). Molecular Cloning: A Laboratory Manual, 2nd edn. Cold Spring Harbor, NY: Cold Spring Harbor Laboratory Press.

SANFORD, J. P. (1984). Leptospirosis - time for a booster. New England Journal of Medicine 310, 524-525.

SEGERS, R. P. A. M. (1991). The molecular analysis of sphingomyelinase gene of Leptospiraceae. $\mathrm{PhD}$ thesis. University of Utrecht, The Netherlands.

SHELDON, W. H. (1953). Leptospiral antigen demonstrated by the fluorescent antibody technique in human muscle lesions of Leptospira icterohaemorrhagiae. Proceedings of Society of Experimental Biology 84, 165-167.

SOUTHERN, E. M. (1975). Detection of specific sequences among DNA fragments separated by gel electrophoresis. Journal of Molecular Biology 98, 503-517.

Terpstra, W. J., Ligthart, G. S. \& Schoone, G. J. (1980). Serodiagnosis of human leptospirosis by Enzyme-Linked-Immunosorbent Assay (ELISA). Zentralblatt für Bakteriologie, Mikrobiologie und Hygiene A. 247, 400-405.

Terpstra, W. J., Jabboury-Postema, J. \& Korver, H. (1983). Immunoperoxidase staining of leptospires in blood and urine. Zentralblatt für Bakteriologie, Mikrobiologie und Hygiene A. 254, 534-539.

TERPSTRA, W. J., Schoone, G. J. \& TER SChegGet, J. (1986). Detection of leptospiral DNA by nucleic acid hybridization with ${ }^{32} \mathrm{P}$ - and biotin-labelled probes. Journal of Medical Microbiology 22, 23-28.

Terpstra, W. J., Korver, H., Schoone, G. J., van Leeuwen, J., SchonemanN, C. E., De Jonge-Aglibut, S. \& KolK, A. H. J. (1987). Comparative classification of Leptospira serovars of the Pomona group by monoclonal antibodies and restriction endonuclease analysis. Zentralblatt für Bakteriologie, Mikrobiologie und Hygiene A. 266, 412-421.

TURNER, L. H. (1970). Leptospirosis III. Maintenance, isolation and demonstration of leptospires. Transaction of the Royal Society of Tropical Medicine and Hygiene 64, 623-646.

WagenaAr, J. A., GaAstra, W., Segers, R. P. A. M. \& van der Zeist, B. A. M. (1991). The detection of pathogenic leptospires by amplification of 16S rRNA sequences. In Leptospirosis. Proceedings of the Leptospirosis Research Conference 1990, The 75th Anniversary of the Discovery of Causal Organism of Weil's Disease by Inada and Ido, p. 165. Edited by Y. Kobayashi. Tokyo: University of Tokyo Press.

WhITE, F. H. \& Ristic, M. (1959). Detection of Leptospira pomona in guinea pig and bovine urine with fluorescein-labeled antibody. Journal of Infectious Diseases 105, 118-123.

DE WIT, M. Y. L., FABER, W. R., KRIEG, S. R., Douglas, J. T., LuCAS, S. B., Montreewasuwat, N., Pattyn, S. R., Hussein, R., Ponnighaus, J. M., Hartskeerl, R. A. \& Klatser, P. R. (1991). Application of a polymerase chain reaction for the detection of Mycobacterium leprae in skin tissues. Journal of Clinical Microbiology 29, 906-910.

Yanisch-Perron, C., Vieira, J. \& Messing, J. (1985). Improved M13 phage cloning vectors and host strains: nucleotide sequences of the M13mp18 and pUC19 vectors. Gene 33, 103-119.

Yasuda, P. H., Steigerwalt, A. G., Sulzer, K. R., KaufmanN, A. F., Rogers, F. \& BRenNeR, D. J. (1987). Deoxyribonucleic acid relatedness between serogroups and serovars in the family Leptospiraceae with proposals for seven new Leptospira species. International Journal of Systematic Bacteriology 37, 407-415. 